\title{
INTRODUCTION TO THE AJIL UNBOUND SYMPOSIUM ON RECOGNITION OF GOVERNMENTS AND CUSTOMARY INTERNATIONAL LAW
}

\author{
James Gatbii*
}

In the lead essay ${ }^{1}$ in this symposium, Professor Erika de Wet contends that notwithstanding all of the postCold War enthusiasm for a right to democratic governance and the non-recognition of governments resulting from coups and unconstitutional changes of government, a customary international law norm on the nonrecognition of governments established anti-democratically has not emerged. De Wet's position, primarily based on state practice in Africa, is vigorously debated by six commentators.

Jure Vidmar ${ }^{2}$ agrees with de Wet that the representative legitimacy of governments still lies primarily in effective control over the territory of the state. Vidmar, in his contribution, examines recent collective practice when neither the incumbent government nor the insurgents control the territory exclusively, arguing that in such cases states may apply human rights considerations. Like de Wet, however, Vidmar regards state practice as ambivalent and unamenable to ideal-type distinctions between coups (against a democratically legitimate government) and regime changes (to a democratically legitimate government).

Contrary to de Wet's account of democratic legitimacy's rocky road since the milestones of Haiti and Sierra Leone in the 1990s, Brad Roth ${ }^{3}$ characterizes its import as only a modest qualification to the doctrine of effective control. Roth also differentiates legitimism that appeals to the state's constitutional norms, from legitimism that appeals to the international community's commitment to (supposed) democratic principles, describing "constitutional legitimism per se [as] nothing more or less than a formula for locking in established elites that have formalized their authority." He argues as long as "the international system remains characterized by a multiplicity of conflicting interests and conflicting political moralities, where implementers of supposed universal values are untrusted . . . a thorough-going democratic legitimism is unpromising as an international norm, and a potential source of mischief as a unilateralist initiative."

Jean d'Aspremont ${ }^{4}$ agrees with de Wet's assessment of the evidence and her conclusion calling into question the existence of a customary international law norm on the non-recognition of unconstitutional changes in government. For him, the further significance of her account is as a reminder of the fragility of international lawyers' "grand regulatory project." He identifies another reminder in de Wet's observation that the ouster of the Yanukovich government in Ukraine (as separate from other states' recognition of its successor) was not a violation of international law. D'Aspremont argues that "it is of little or no avail to try to think of

* Wing-Tat Lee Chair in International Law and Professor of Law at Loyola University Chicago.

Originally published online 16 Jan. 2015.

${ }^{1}$ Erika de Wet, From Free Town to Cairo via Kiev: The Unpredictable Road of Democratic Legitimacy in Governmental Recognition, 108 AJIL UNBOUND 201 (2015):

2 Jure Vidmar, Democratic Legitimacy Between Port-au-Prince and Cairo: A Reply to Erika de Wet, 108 AJIL UnBOUnD 208 (2015).

3 Brad R. Roth, Whither Democratic Legitimism?: Contextualizing Recent Developments in the Recognition and Non-recognition of Governments, 108 AJIL UNBOUND 213 (2015).

${ }^{4}$ Jean d'Aspremont, The Pipe Dream of Constraining Recognition Through Democracy: International Lawyers' Regulatory Project Continued, 108 AJIL UNBOUND 219 (2015).

ASIL and James Gathii (C) 2015 
changes of government in terms of violations of international law" in part because under the law of state responsibility, it is not possible to establish the subjective element necessary for an internationally wrongful act.

In contrast to de Wet's negative conclusion based on customary international law, Christina Cerna ${ }^{5}$ concludes from treaty obligations such as those set forth in both the Charter of the Organization of American States (OAS) and the Inter-American Democratic Charter, as well as comparable European and African instruments, that democratic legitimacy and human rights have replaced "effective control" as criteria for the recognition of governments. Also focusing on international treaty law, Obiora Okafor ${ }^{6}$ invites de Wet to clarify whether at the global level there are treaty provisions from which it follows that the recognition of undemocratically installed governments is prohibited or discouraged; notably, the right of self-determination of peoples contained in common Article 1 of the International Covenant on Civil and Political Rights and the International Covenant on Economic, Social and Cultural Rights. In the final response, Vasiliki Saranti ${ }^{7}$ seeks to show that democratic legitimacy as a criterion for the recognition of governments has gained special momentum in the OAS framework and that there are good reasons to contend that such a rule is becoming a regional customary international law rule in the Americas.

In short, this is an engaging symposium with very well argued essays on all sides of the debate. AJIL Unbound thanks the seven authors for their thoughtful and provocative pieces.

${ }^{5}$ Christina M. Cerna, Democratic Legitimacy and Respect for Human Rights: The New Gold Standard, 108 AJIL UnBOUnD 222 (2015).

${ }^{6}$ Obiora Chinedu Okafor, Democratic Legitimacy as a Criterion for the Recognition of Governments: A Response to Professor Erika de Wet, 108 AJIL UnBOUnd 228 (2015).

7 Vasiliki Saranti, Democratic Legitimacy as a Criterion for Recognition of Governments: A Response to Professor Erika de Wet, 108 AJIL UNBOUND 233 (2015). 